\title{
The California Supreme Court and Selective Review
}

In a two-tiered appellate court system, the highest court may decide either some or all of the issues presented in an appeal from a lower appellate court. If the highest court decides all of the issues presented, then its opinion necessarily supersedes that of the lower appellate court. On the other hand, if the highest court decides only some of the issues presented, then those that it does not decide remain governed by the opinion of the lower appellate court. This latter procedure, known as selective review, enables the highest court to consider only those issues that it feels are worthy of its attention. Thus, by its very nature, selective review creates an efficient appellate process.

California is one of three jurisdictions in the United States that does not presently use selective review. ${ }^{1}$ Instead, when a case decided by the California Court of Appeal is transferred to the California Supreme Court, the high court must hear the casc as if it were originally appealed there. ${ }^{2}$ The court of appeal decision is vacated and the accompanying opinion is considered a nullity. ${ }^{3}$ Thus, although the California Supreme Court is not required to transfer an appeal from the court of appeal, ${ }^{4}$ when it chooses to review a court of appeal decision, it must decide anew all of the relevant issues. As one commentator has suggested, the court faces "a choice between a 16-inch gun and nothing." 5

This Comment proposes that California should adopt the more efficient procedure of selective review. Part I discusses the present state

1. Indiana and Missouri are the other two jurisdictions. By court rule, Indiana court of appeals decisions are vacated upon transfer to the state supreme court. IND. R. APp. Proc. 11(B)(3). See also O'Connor v. O'Connor, 253 Ind. 295, 305, 253 N.E.2d 250, 255 (1969); Southern Ry. v. Ingle, 117 Ind. App. 229, 233-34, 69 N.E.2d 746, 748 (1946). The Missouri Constitution and the Missouri Rules of Civil Procedure permit the Missouri Supreme Court to determine causes from the court of appeals "the same as if on original appeal." Mo. Const. art. V, $\$ 10$; MO. R. Clv. PROC. 83.09. Although worded permissively, these provisions have been interpretcd to require that the court of appeals decision be vacated. See Hunt v. Hunt, 423 S.W.2d 682, 684 (Mo. 1968); State ex rel. State Highway Comm'n v. Long, 422 S.W.2d 276, 277 (Mo. 1968); Cornet \& Zerbig, Inc. v. 430 Withers Realty Co., 415 S.W.2d 751, 753 (Mo. 1967).

2. Ponce v. Marr, 47 Cal. 2d 159, 161, 301 P.2d 837, 839 (1956).

3. See infra text accompanying notes $60-68$.

4. The appellate jurisdiction of the California Supreme Court is discretionary. See infra text accoinpanying notes $48-51$.

5. Carrizosa, Opinions Issued by State High Court Decline in Number, L.A. Daily J., Apr. 16, 1981, at 1, col. 6, 5, col. 6 (quoting Ed Lascher of the California Academy of Appellate Lawyers). 
of overcrowding at the supreme court level that makes the adoption of selective review particularly necessary. Part II examines how the California court system arrived at an interpretation of the state constitution that prevents the use of selective review. Part III analyzes various procedures the supreme court has used to circuinvent the rule prohibiting selective review. Fmally, Part IV describes the advantages of selective review, and concludes that the procedure should be adopted by either a reinterpretation of the court's transfer powers under the constitution, or by amendment of the constitution.

\section{CURRENT COURT OVERCROWDING}

The serious overcrowding presently facing the supreme court highhights the need for the efficiency advantages of selective review. The Cabifornia court system is the largest and busiest in the world. ${ }^{6}$ It has also been the fastest growing, ${ }^{7}$ due primarily to California's population boom. ${ }^{8}$ Although the tremendous increase in demand for judicial services has resulted in an almost continuous state of overcrowding at all levels of the system, ${ }^{9}$ the problein is particularly acute at the state supreme court level. Whereas the number of judges at the other levels has imcreased with the demand for their services, ${ }^{10}$ the supreme court has in recent times remained a single decisionmaking body of seven members. ${ }^{11}$

6. H. Kushner \& H. Nisselson, Problems in the Management of the Courts of CALIfornia 2 (1969) (Report for Hon. William T. Bagley, Chairman, Assembly Judiciary Committee) [heremafter cited as KUSHNER].

7. Id. at 9.

8. See Gustafson, Some Observations About California Courts of Appeal, 19 U.C.L.A. L. REv. 167, 168 (1971); KusHNER, supra note 6, at 55. Other reasons for the growth in demand for judicial services imclude a higher proportion of felony filings, see id. at 9 , imcreased urbanization, the expansion of crimmal, prisoner, and consumer rights, and the imcreased use of the courts as a means to effect social change, see National Center for State Courts, The California COURTS OF APPEAL 1 (1974).

9. See, e.g., In re Wells, 174 Cal. 467, 471-72, 163 P. 657, 658 (1917) (discussing the effect of growth in state's population upon organization of state courts); 3 E. Willis \& P. STOCKroN, Debates and Proceedings of the Constitutional Convention of the State of CaliforNIA 1455 (1881) (remarks of Mr. Wilson); Leavitt, The Yearly Two Foot Shelf: Suggestions for Changing Our Reviewing Court Procedures, 4 PAC. L.J. 1 (1973); Radin, The Requirement of Written Opinions, 18 CALIF. L. Rev. 486, 493 (1930); Special Committee re Appellate Courts, The Court of Review: A New Court for California?, 47 CAL. ST. B.J. 28 (1972); Provides Appellate Courts, San Francisco Chron., Mar. 14, 1903, at 5, col. 3. But see Chilton, Appellate Court Reform: The Premature Scalpel, 48 CAL. Sr. B.J. 393, 468 (1973). The California court system has been burdened from the state's very beginning due to the great influx of people during the Gold Rush of the mid-1800's. See Introduction to 24 Cal. i, i-iv (1865).

10. See, eg., Gustafson, supra note 8, at 168-69.

11. See infra text accompanying note 32 . Since 1929, the court has not heard cases in semiautonomous departments. See infra note 37. 
The increase in the number of matters that the supreme court must review illustrates the tremendous workload facing the court today. In fiscal year 1961-62, the supreme court received 803 petitions for hearing and granted 122.12 But in 1981-82, the court received 3,338 petitions and granted $280 .{ }^{13}$ Together with its original proceedings, clemency applications, attorney disciplinary proceedings, and other court work, the supreme court faced a record 7,735 matters in 198182. ${ }^{14}$ This figure translates into an overwhelming weekly workload. For example, while only twenty years ago the court faced roughly forty matters at its weekly Wednesday conference, ${ }^{15}$ today it must consider between 100 and 160 petitions for hearing each week. ${ }^{16}$

Moreover, because the Cahforina Constitution provides the supreme court with original appellate jurisdiction where the judgment of death has been pronounced, ${ }^{17}$ the swelling number of death-penalty cases adds to the overcrowding problem. With 145 such appeals currently pending ${ }^{18}$ the backlog of these cases alone represents almost an entire year's worth of cases for the court. ${ }^{19}$ Moreover, this backlog con-

12. 1973 Jud. Councll CAL. ANn. Rep. 176.

13. 1983 JUd. Councll CAL. ANN. Rep. 77. This tremendous increase in the number of petitions for hearing reduces the possibility of a litigant having his or her case heard by the supreme court. For example, although the court granted $15.2 \%$ of all petitions for hearing filed in 1961-62, 1973 Jud. Councll CAL. ANN. Rep. 176, this rate had dropped to $8.4 \%$ in 1981-82, 1983 Jud. Council Cal. ANn. Rep. 81.

14. 1983 Jud. Councll Cal. Ann. Rep. 77.

15. P. Stolz, Judging Judges 194 (1981).

16. Carrizosa, Profile, L.A. Daily J., Jan. 2, 1984, at 1, col. 3 (interview with Chief Justice Rose Bird). The court typically meets each Wednesday morning, approximately 40 weeks out of the year, to discuss petitions and other matters presented to it. See Grodin, The Depublication Practice of the California Supreme Court, 72 CALIF. L. Rev. 514 (1984).

17. CAL. ConST. art. VI, $\S 11$. With the exception of death penalty cases, original appellate jurisdiction of cases originating in the superior courts lies with the courts of appeal, and original appellate jurisdiction of cases originatimg in the municipal or justice courts lies with the superior courts. Id. As of the publication date of this Comment, a constitutional amendment to remove original appellate jurisdiction of death penalty appeals from the supreme court was pending before the state legislature. See Senate Const. amend. No. 45 (imtroduced by Senator Maddy, Jan. 11, 1984).

18. Fogarty \& Carlsen, Key Ruling On Death Penalty Law, San Francisco Chron., Jan. 24, 1984 , at 1 , col. 3 .

19. The supreme court possesses the ability to transfer cases from itself to the courts of appeal for decision, CAL. ConsT. art. VI, $\S 12$. It has been suggested that the court make use of this power to reduce its backlog of death penalty cases. See, e.g., Kleps, Can Our Supreme Court Survive?, L.A. Daily J., Aug. 18, 1982, at 4, col. 4. This procedure appears to be constitutionally permissible, although both prosecution and defense attorneys have argued against its inplementation. Id. Prior to the 1966 revision of the California Constitution, the supreme court held original appellate jurisdiction in a great number of civil matters, yet routinely transferred such cases to the courts of appeal for decision under article VI, § 12 (then article VI, § 4). The 1966 revision incorporated this practice and gave the courts of appeal original appellate jurisdiction in such matters, leaving the supreme court sole original appellate jurisdiction only in death penalty cases. Thus, 
tinues to grow at an alarming rate. ${ }^{20}$ For example, in 1981-82, fortythree new death penalty appeals were filed, but the supreine court decided only three death penalty cases. $^{21}$

The sheer nuinber of matters facing the supreine court affects the court's ability to perform its duties. As the amount of time the court must spend reviewing petitions for hearing imcreases, the amount of time available to hear and decide cases necessarily decreases. ${ }^{22}$ Additionally, the court must increasingly rely on its staff to review petitions and draft opinions, which raises serious delegation of responsibility questions. ${ }^{23}$ Perhaps more importantly, this diminished ability to hear and decide cases coines at a time when the similarly overburdened inferior appellate courts are, in their own haste, more likely to err in their application of the law. ${ }^{24}$ Thus, the supreme court finds itself in the

although the court has never chosen to exercise its transfer power in death penalty cases, there is nothing in the constitution prohibiting this procedure.

It can be argued that the intent behind leaving the original appellate jurisdiction of death penalty cases with the supreme court was to ensure that the death penalty would not be pronounced without the opportunity for suprene court review. Although the supreme court could still transfer death penalty cases to the courts of appeal, under this argunent it would be required to grant a petition for hearing after decision by the lower court. Such a requirement would diminish, but not ehminate, the efficiency advantages of the transfer procedure, because if the procedure is used in conjunction with selective review, the court of appeal could reduce the number of issues that the supreme court must decide. Additionally, some death penalty sentences undoubtedly would be overturned by the court of appeal, naking the transfer to the supreme court unnecessary. Nonetheless, the death penalty is a particularly sensitive political issue, and the supreme court may therefore sense that using its transfer powers to avoid deciding a death penalty case could be viewed by the public as a pohtical ploy.

Other suggested means of handling the onslaught of death penalty cases include a return to the use of supreme court commissioners or estabhishment of a separate death penalty court of review. See Kleps, supra.

20. It should be noted that a recent decision by the United States Supreme Court concerning proportionality review in death sentences has removed a major stunibling block to the California Suprene Court's ability to decide death penalty cases. The United States Supreme Court held that proportionality review is not required under the U.S. Constitution, thereby upholding California's death penalty review procedures. This decision should allow quicker decisions by the court in these cases. Pulley v. Harris, 104 S. Ct. 871 (1984).

21. 1983 Jud. Councll Cal. AnN. Rep. 80.

22. Appellate review by the Cahfornia Suprenie Court is discretionary, e.g., People v. Davis, 147 Cal. 346, 349, 81 P. 718, 719 (1905), except in cases where the death penalty has been iniposed. CAL. ConsT. art. VI, \& 11; see infra tcxt accoinpanying notes 48-51. While in 1961-62 the supreme court was able to issue 171 written opinions, 1973 JUD. COUNCIL ANN. REP. 174, by 1981-82 this number had fallen to 123. 1983 Jud. Council Cal. ANn. Rep. 80. See also Carrizosa, supra note 5 (stating that the average number of written opinions issued during the late 1960's under Chief Justice Roger Traynor was 200, and suggesting that the decline in number may be a contributing factor to the overall loss of prestige of the Cahifornia Supreme Court).

23. See Grodin, supra note 16, at 518; Thompson, Mitigating the Damage-One Judge and No Judge Appellate Decisions, 50 CAL. ST. B.J. 476, 514-16 (1975); Morrow, Janofsky Hits State High Court's Review Process, L.A. Daily J., Feb. 29, 1980, at 1, col. 7 (American Bar Association President Leonard Janofsky, in a speech before the Los Angeles County Bar Association, calling the court's rehance on its staff to write opinions "dangerous").

24. See Counment, Case Dispositions by the California Supreme Court: Proposed Alternatives, 
unfortunate position of being less able to fulfill its supervisory role over the inferior courts at a time when this role has become increasingly important. ${ }^{25}$

\section{1 \\ Historical Development}

The California Supreme Court does not employ selective review for two reasons. First, the practice conflicts with the rule requiring that decisions of the courts of appeal be vacated upon transfer of the "cause" to the supreine court for hearing. Second, selective review conflicts with the rule equating "cause" with "case." These two rules evolved from judicial interpretation of a series of constitutional amendments affecting the organization of the California appellate court system.

\section{A. Major Constitutional Developments}

Under the State's constitution of 1849 , the supreme court sat as the primary appellate body. ${ }^{26}$ As such, it was responsible not only for overseeing the development of the common law in California (institutional review), but also for ensuring that the law was properly applied

67 CALIF. L. Rev. 788, 789 (1979); Moore, Bird Calls It Assembly-Line Justice, San Francisco Chron., Jan. 24, 1978, at 10, col. 1. See generally Thompson, supra note 23, passim (discussing how appellate court assembly line tecliniques may produce unacceptably defective decisions).

25. See Comment, supra note 24 , at 789 (Due to time constraints "the supreme court can no longer review cases that would have been considered significant enough to warrant a hearing in previous years. Thus, in being forced to confine its attention to the 'great and important' cases, the court's supervisory function is being undermined."); see also NATIONAL CENTER FOR STATE CouRTs, supra note 8 , at 1.

Recently, a number of proposals have been made to reduce the burden on the supreine court. One proposal is to remove attorney disbarments and suspensions from the supreme court's supervisory jurisdiction under CAL. Bus. \& Prof. Code $\$ 6100$ (West 1980). See Comment, Attorney Discipline and the California Supreme Court: Transfer of Direct Review to the Courts of Appeal, 72 CALIF. L. REv. 252 (1984). Another proposal would ehimmate supreine court review of Public Utility Commission decisions under CAL. Pub. UTIL. CoDE $\S 1756$ (West 1975), and pardons under CAL. ConsT. art. V, $\S 8$. See Chilton, supra note 9, at 468. Additionally, it has been suggested that there be a reduction in the hearings of oral argument and an increased use of summary dispositions. See, e.g., id. at 467; Leavitt, supra uote 9, at 18-26. A court of review has also been proposed that would add an additional level of review to the appellate process. See Special Coinunittee re Appellate Courts, supra note 9; see also Chilton, supra note 9, at 396-97; Hufstedler \& Hufstedler, Improving the California Appellate Pyramid, 46 L.A.B. BuLL. 275, 298-302 (1971); Leavitt, supra note 9, at 10-14. Most recently, Justice Stanley Mosk and Governor George Deukmejian have suggested adding four justices to the supreme court and splitting the court into a civil and criminal division. See Wiegand, Deukmej̈an Will Back Plan To Split Top Court, San Francisco Chron., Nov. 12, 1983, at 1, col. 3.

26. The supreme court held sole appellate jurisdiction except in cases decided by justices of the peace, where original appellate jurisdiction lay with the county courts. CAL. CoNST. art. VI, $\S 8$ (1849). 
in each case (correctional review). ${ }^{27}$

As one part of the review process, the supreme court could, after reaching a decision, order the rehearing of a case, and such an order would nullify the court's prior opinion. ${ }^{28}$ Although the language of the 1849 constitution did not require this result, the supreme court believed that this procedure followed directly from the very nature of a rehearing. ${ }^{29}$

\section{Constitutional Developments in 1862 and 1879 -Increasing the Size of the California Supreme Court}

Since its establishınent under the 1849 constitution, the supreine court has faced an ever-increasing workload, which has precipitated a series of constitutional amendinents affecting the size of the court and the scope of its appellate jurisdiction. In 1862, an amendment expanded the original three-member court to five members. ${ }^{30}$ Yet, by 1879 , the workload of the court had again reached the point where its five inembers were no longer able to discharge their duties. They had fallen behind on their calendars, and were unable to issue written opinions in nearly one-half of their cases. ${ }^{31}$

In response to this problein, the constitutional convention of 1879 altered the judicial structure by expanding the court from five to seven inembers and dividing the justices into two departments. ${ }^{32}$ Under this

27. See generally Hufstedler \& Hufstedler, supra note 25, at 278-79; Special Committee re Appellate Courts, supra note 9, at 30-33; Comment, supra note 24, at 797-801. But see Chilton, supra note 9, at 469-72, which argues against the establishment of a Court of Review: "Even assuming arguendo that one could analytically distinguish between 'review for correctness' and 'institutional review,' it is quite obvious that the difference is inperceptible in reality." Id. at 470.

28. See, e.g., Argenti v. San Francisco, 16 Cal. 255 (1860), where the court stated that "[w]hen a rehearing is granted, the opinion previously delivered falls, unless reaffirmed after the reargument. Until such reaffirmance, the opinion never acquires the force of an adjudication, and is entitled to no more consideration than the briefs of counsel." Id. at 276.

This result is not dictated by either statute or constitution; rather, it is a matter of judicial interpretation. See Seale v. San Francisco, 16 Cal. 284 (1860); Argenti v. San Francisco, 16 Cal. 255 (1860).

29. See, e.g., People v. Murphy, 108 Cal. App. 3d 475, 478, 166 Cal. Rptr. 547, 548 (1980); 5 CAL. JuR. 3D Appellate Review $\$ 425$ (1973).

30. CAL. ConST. of 1849, art. VI, $\$ 2$ (1862). See also Introduction to 24 Cal. i, i-iv (1865).

31. 3 E. Willis \& P. Stockton, supra note 9, at 1455 (remarks of Mr. Wilson). The supreme court at that time was not required to render written opinions, having previously declared an 1850 statute, which required the court to write all its opinions, unconstitutional. Honston v. Williams, 13 Cal. 24 (1859). The requirement of written opinions first appeared in the California Constitution in 1879, CAL. CoNST. art. VI, $\S 2$ (1879), and today is found in CAL. CoNST, art. VI, $\S 14$ (adopted in 1966). See Radin, supra note 9; Colninent, Publish or Perish: The Destiny of Appellate Opinions in California, 13 SanTa ClaRa L. Rev. 756, 757 \& n.10 (1973). See also Blume, California Courts in Historical Perspective (pt. 2), 22 Hastings L.J. 121, 161 (1970).

32. CAL. ConsT. art. VI, \$ 2 (1879). The convention rejected an alternate plan to establish a court of appeals. See 3 E. Willis \& P. Stockton, supra note 9, at 1455 (reunarks of Mr. Wilson). The court of appeal plan was apparently rejected because of the unsatisfactory results obtained 
new scheme, the chief justice exercised a great deal of authority over the departments, including the power to assign the justices to each departinent, to apportion the workload between departments, and to sit with either department at his or her own discretion..$^{33}$

In addition, to prevent the two departments from developing divergent lines of authority, the chief justice could require that any "cause" decided by a department be heard by the court sitting in bank. ${ }^{34}$ The order granting a hearing by the court im bank, like an order granting a rehearing by the court's historical predecessor, ${ }^{35}$ vacated and set aside the prior judgment of the department. ${ }^{36}$ However, unlike the rule developed by the earlier court regarding rehearings, the 1879 constitution explicitly required that the department's judgment be rendered a nullity: "[I]t shall have the effect to vacate and set aside the judginent." ${ }^{37}$

\section{The Constitutional Amendment of 1904 -Creation of the District Court of Appeal}

By the turn of the century, the supreme court workload, fueled by the expanding population of the state, had increased to the point that additional constitutional reforn was required. ${ }^{38}$ However, the state legislature rejected a proposal to once agam increase the size of the court and add a new department. ${ }^{39}$ Instead, the legislature ${ }^{40}$ approved

with the New York Court of Appeals, which had at that time become "a sort of receptacle for worn out old Judges," $i d$, and was often in conflict with the state supreme court. Id.

33. CAL. Const. art. VI, $\$ 2$ (1879).

34. Id. See In re Jessup, 81 Cal. 408, 470, 22 P. 1028, 1031 (1889) (opinion on rehearing). See generally In re Wells, 174 Cal. 467, 471, 163 P. 657, 659 (1917).

The California Constitution uses the term "in bank" to refer to the court sitting with all its members, rather than the traditional term "en banc."

35. See supra text accompanying notes 28-29.

36. CAL. Const. art. VI, $\S 2$ (1879). See also In re Wells, 174 Cal. at 471,163 P. at 659.

37. CAL. Const. art. VI, $\S 2$ (1879). This provision, together with the department structure, was removed from the constitution in the 1966 revision, because the court had not sat in departments simce 1929. See Comment, supra note 24, at 796 n.48; Comment, Courts: Significance of the Practice of the California Supreme Court of Commenting on the Opinion of the District Court of Appeal When Denying a Hearing After Judgment, 28 CALIF. L. Rev. 81,86 n.24 (1939).

38. Such reform was proposed in $\mathbf{1 8 9 9}$ in the form of an amendment establishing a court of appeal. This proposal passed the state legislature, Act of March 18, 1899, ch. 37, \&3, 1899 Cal. Stat. 503, 504-07, but was narrowly defeated in the November 6, 1900 general election by a vote of 79,354 against to 69,997 in favor. See C. CuRry, CALIFORNIA's Vote IN 1900, at 15 (1900).

39. 1903 Cal. Assembly J. 1246 (Assembly Const. amend. No. 3, passed on file March 4, 1903).

40. The California constitution may be amended by initiative, constitutional convention, or by a proposal passed by two-thirds of both houses of the State Legislature. The latter method, used im 1904, requires the subsequent approval of the electorate. CAL. Const. art. XVIII, $\S 1$. Voters approved the amendment in the general election of November 8, 1904, by a vote of 93,306 in favor to 36,277 against. See C. Curry, Statement of the Vote of California at the General Election, held November 8, 1904, at 10 (1904). 
an amendment that would establish an entirely new appellate level: the district court of appeal. ${ }^{41}$

The amendment was designed to relieve the docket pressure and delays confronting the supreine court:

At the time this constitutional amendment was put forward and adopted this court had been for years unable to dispose of the business before it as fast as it accumulated, and the cases were decided from two to three years after the appeals were filed. . . . The amendment was adopted chiefly for the purpose of affording a remedy for this evil. ${ }^{42}$

The amendment divided the state into three appellate districts, each with one district court of appeal composed of three judges. ${ }^{43}$ The supreine court was given the power to transfer cases over which it had exclusive appellate jurisdiction to the district courts of appeal for review, ${ }^{44}$ and to move cases from one district court of appeal to another to even out the workload. ${ }^{45}$ Additionally, the supreme court was given the power to transfer a case from a district court of appeal to itself, either before the district court of appeal had rendered its judgment, or within thirty days after its decision. ${ }^{46}$

Unfortunately, the amendment left several critical issues unresolved. First, the annendment did not establish whether litigants had an appeal of right from the district court of appeal to the supreme court. Second, it was unclear whether the transfer of a "cause" to the supreme court, after judgment by the district court of appeal, autonatically vacated that prior decision. Third, the amendment did not determine whether "cause" could be imterpreted to mclude less than all of the issues in a case. Finally, the amendment did not explicitly resolve the question of the proper division of responsibility between the supreme court and the district court of appeal. However, judicial interpretation of the amendment and its imtent soon resolved each of these issues.

41. Act of March 14, 1903, ch. 38, 1903 Cal. Stat. 737 (Senate Const. amend. No. 2) (Senator Hahn). Curiously, the 1899 proposal labeled the court the "court of appeal," rather than the "court of appeals," as was found in the 1879 proposal. This awkward language was carried forward to the 1904 amendment establishing the "district court of appeal." In 1966, the word "district" was removcd.

42. People v. Davis, 147 Cal. 346, 349, 81 P. 718, 720 (1905).

43. CAL. Const. art. VI, $\$ 4$ (1904). The new courts were given appellate jurisdiction over a wide range of cases, including most crimmal and writ appeals, as well as civil appeals not arising in equity froin the superior courts, where the amount in controversy was at least $\$ 300$ but less than $\$ 2,000$. Id.

44. Id.

45. Id; see also Davis, 147 Cal. at $347-48,81$ P. at 719.

46. CAL. ConST. art. VI, $\$ 4$ (1904) provided the supreme court with the power "to order any cause pending before a District Court of Appeal to be heard and deternmimed by the Supreme Court. The order . . . inay be made before judgment has been pronounced by a District Court of Appeal, or within thirty days after such judginent shall becoine final therem." $I d$. 


\section{B. Judicial Interpretation of the 1904 Constitutional Amendments}

The supreme court first interpreted its relationship with the newly established district court of appeal in People v. Davis. ${ }^{47}$ Davis presented the novel question wliether a litigant liad a right to appeal from the district court of appeal to the supreme court. It also addressed the respective roles that the supreme court and district court of appeal would play with respect to institutional and correctional review.

\section{Supreme Court's Transfer Power is Discretionary-People v. Davis}

The issue before the court in Davis was whether or not the exercise of its transfer powers was discretionary. To decide this issue, the court looked first to the language of the 1904 constitutional amendment. ${ }^{48}$ The court noted that a cause transferred while pending before, but not yet decided by, the district court of appeal was by definition an appeal from the superior court. The court then reasoned that since the amendment made no distinction between an appeal transferred before judgment by the district court of appeal and an appeal transferred after judgment, it followed that a post-judgment transfer must also be an appeal directly from the superior court. ${ }^{49}$ The court then concluded that the new constitutional transfer provision made reference to but one appeal. ${ }^{50}$ Simce the hitigant's constitutional right to an appeal had already been satisfied by review in the district court of appeal, another appeal before the supreme court was not required. ${ }^{51}$ Thus, the transfer power was purely discretionary.

47. 147 Cal. 346,81 P. 718 (1905).

48. See supra note 46.

49. Davis, 147 Cal. at $348-49,81$ P. at 720 .

50. Id. at $349,81 \mathrm{P}$. at 720 .

51. At the time of Davis, the right to appeal was found to be constitutionally based. In re Estate of Nelson, $128 \mathrm{Cal} .242,245,60$ P. 772, 773 (1900) ("The right of appeal is conferred by the constitution, and statutes and rules of procedure for its exercise are to be liberally construed."). Since then, by the subtle change of the position of a comma, this right has been described as based on both statute and constitution. See, e.g., Lane v. Pellissier, $208 \mathrm{Cal}$. 590, 595, 283 P. 810,812 (1929) (Shenk, J., dissenting) ("[T]he right of appeal in this case is conferred by the Constitution and statutes, and rules of procedure for its exercise are strictly construed in favor of the party desiring the review."); see also Cullinan v. Superior Court, 24 Cal. App. 2d 468, 472, 75 P.2d 518, 520 (1938) ("The right of appeal is not inherent to a legal proceeding, but is dependent upon either constitutional or legislative approval."). The right has also been declared to be solely statutorily based. See, e.g., Superior Wheeler Cake Corp. v. Superior Court, 203 Cal. 384, 389, 264 P. 488 , 488 (1928); Jackson v. Jackson, 71 Cal. App. 2d 837, 839, 163 P.2d 780, 781 (1945). The right has also been declared to be based on a theory of the appellate system. See, e.g., People v. Groves, 9 Cal. App. 2d 317, 323, 50 P.2d 813, 814 (1935) (denying rehearing) ("[U]nder the theory of our appellate system, justice and due process are satisfied if the unsuccessful litigant is given one opportunity for review by a higher court, and that finality is intended to accoinpany the judgments 
2. The Division of Responsibility Between the Supreme Court and the District Court of Appeal-Institutional and Correctional Review

To support its decision further, the Davis court looked to the purpose of the 1904 amendment: to reduce the workload and backlog of the supreme court. ${ }^{52}$ Specifically, the court addressed the proper division of responsibility between the respective courts:

If this court shall now adopt the policy of inquiring into the facts of each case in [the district court of appeal], we would be required to examine minutely the records and briefs of each case there decided in which our intervention was invoked, to ascertain whether or not the facts involved were accurately stated and considered in the opinion of that court. This would involve this court in a vast amount of additional labor, and would in great measure defeat the object which the amendment was intended to secure. ${ }^{53}$

From this investigation into the purpose of the amendment, the court concluded not only that its review was discretionary, but more important, that the amendment was intended to relieve the suprene court of the need to perform correctional review. That role was to be fulfilled by the district courts of appeal. ${ }^{54}$ The supreme court, on the other hand, would oversee the development of the law. It would prevent divergent lines of cases from developing, both among the various divisions of the district court of appeal, and between its own departments. 55 Thus, the court concluded that it would "not hold itself bound ... to order a transfer of the cause, after a decision of the district

of the District Courts of Appeal. The Supreme Court should not be required to review the case unless the opinion contains a bad precedent.") (emphasis in original).

The current statutory basis of the right to appeal is found in CAL. CIv. Proc. CODE $\$ \S 901$ 904.5 (West 1980 \& Supp. 1984).

52. People v. Davis, 147 Cal. 346, 348-49, 81 P. 718, 720 (1905); see supra text accompanymg note 42.

53. Davis, 147 Cal. at 349,81 P. at 720 (emphasis added).

54. More specifically, the court stated that "[t]he district courts of appeal are established for the purpose of ascertaining and enforcing, according to the rules of law, the particular right of each case committed to their arbitrament." Id.

55. Scala v. Jerry Witt \& Sons, Inc., 3 Cal. 3d 359, 475 P.2d 864, 90 Cal. Rptr. 592 (1970), represents a modern example of the supreme court performing its role of ensuring the uniformity of decision. Two years prior to Scala, the supreme court had interpreted CAL. CIV. PROC. CODE $\$ 657$ to require a judge ordering a new trial for insufficiency of the evidence to recite briefiy the gruands on which he or she found evidence to be insufficient. Mercer v. Perez, 68 Cal. 2d 104, 436 P.2d 315, 65 Cal. Rptr. 315 (1968). Two lines of cases then developed in the courts of appeal. The first, a line of ten cases following the reasoning of Funderburk v. General Tel. Co., 262 Cal. App. 2d 869, 69 Cal. Rptr. 275 (1968), held that a cursory specification of reasons satisfied $\S 657$. The second, led by McLaughlin v. City of San Francisco, 264 Cal. App. 2d 310, 70 Cal. Rptr. 782 (1968), held that a recitation of the ultinate fact was an inadequate statement of grounds under $\S 657$. In Scala, the supreme court expressly disapproved the Funderburk line, thus ensuring that future courts would uniformly follow the McLaughlin rule in applying $\S 657$. Scala, 3 Cal. 3d at 366,475 P.2d at 868,90 Cal. Rptr. at 596. 
court, except where it shall appear necessary in order to carry out the . . purposes of securing uniformity of decision and the settlement of important questions of law."56

Unfortunately, this division of judicial responsibihty between the supreme court and the district court of appeal could only be accomplished if the latter court had appellate jurisdiction over the matter and was therefore able to perform correctional review. To overcome this obstacle, the supreme court began to use its transfer power to expand the jurisdiction of the district court of appeal mto areas in which the 1904 amendment had not provided it with original appellate jurisdiction. ${ }^{57}$ In addition, the court generally refused to hear cases brought initially before it, where it shared appellate jurisdiction with the district court of appeal. ${ }^{58}$ In this way, the court confined itself to institutional review and limited the instances in which it had to perform correctional review.

\section{Transfer of a Cause to the Supreme Court Vacates the District Court of Appeal's Decision-Noel v. Sinith}

The rule that the transfer of a cause to the supreme court vacates the decision of the district court of appeal was first stated by the district court of appeal in Noel v. Smith. ${ }^{59}$ There, the court held that "[s]uch an order will have the effect to set aside and vacate the judgment of the district court of appeal, and with it the value, as an authority, of the opinion upon which the decision was rendered." 60

Unfortunately, the Noel court provided no rationale for this holding. However, it apparently analogized a transfer from the district

56. Davis, 147 Cal. at $350,81 \mathrm{P}$. at 720 (emphasis added). These standards were eventually incorporated into the California Rules of Court, which provide:

A hearing in the Supreme Court after decision by a Court of Appeal will be ordered (1) where it appears necessary to secure uniformity of decision or the settlement of important questions of law; (2) where the Court of Appeal was without jurisdiction of the cause; or (3) where, because of disqualification or other reason, the decision of the Court of Appeal laeks the concurrence of the required majority of qualified judges.

CAL. CT. R. 29(a).

57. See supra note 43. The frequent expansion of the jurisdiction of the district court of appeal in this manner eventually resulted in a 1966 constitutional change giving the district court of appeal origimal appellate jurisdiction over all appeals from the superior courts, except those involving a judgment of death. CAL. CoNST. art. VI, $\$ 11$ (adopted 1966).

58. See Collins v. Superior Court, 147 Cal. 264, 81 P. 509 (1905), where the court stated:

We desire in the outset to make a precedent to be followed in like cases hereafter:

When a case is such that an appeal from the judgment of the lower court would properly be taken to the district court of appeal, a petition to prohibit the proceeding should be addressed to that court.

Id. at 264-65, $81 \mathrm{P}$. at 509 (transferring the case to the district court of appeal under CAL. ConsT. art. VI, § 4 (1904)).

59. 2 Cal. App. 158, 83 P. 167 (1905). The decision of the district court of appeal in Noel followed that of the supreme court in Davis by just a few months.

60. Noel, 2 Cal. App. at 161, 83 P. at 169 . 
court of appeal to the supreme court to a transfer from a department of the supreme court to the court sitting in bank. ${ }^{61}$ Thus, the court construed the constitutional language vacating department decisions upon the grant of rehearing by the supreme court in bank as also applying to cases transferred to the supreme court from the district court of appeal. ${ }^{62}$

Although Noel was decided by a district court of appeal, the supreme court soon followed the same rule. ${ }^{63}$ A later case declared Noel to be "entitled to great weight in the construction of that amendment" because it was the first case to interpret this facet of the 1904 a1nendment. ${ }^{64}$ Moreover, the hist of authority in support of the rule is impressive $^{65}$ and almost unbroken. ${ }^{66}$ An often-quoted passage from Knouse v. Nimocks ${ }^{67}$ summarizes the state of the law:

The opinion and decision of the District Court of Appeal, by our order of transfer, have become a nullity and are of no force or effect, either as a judgment or as an authoritative statement of any principle of law therein discussed. . . . [T]he opinion may serve as a brief on the legal questions imvolved therein, and may be adopted by this court as its opimion in the pending action. But without some further express act of approval or adoption of said opinion by this court, that opinion and decision are of no more effect as a judgment or as a precedent to be followed in the decision of legal questions that may hereafter arise than

61. Although the interpretation of the language of the 1904 amendment in Davis suggested this resnlt, see supra text accompanying note 49 , Davis was not cited in Noel or in any later decision holding the district court of appeal decision vacated upon a transfer to the supreme court. See, e.g., cases cited infra at note 65 .

62. See CAL. CoNST. art. V1, § 2 (1879) (emphasis added): "[W] ted to one of the departments, and a judgment pronounced thereon, the order inust be made within 30 days after such judgment, and if so made it shall have the effect to vacate and set aside the judgment." (emphasis added); see also supra note 37.

63. See, e.g., People v. Clark, 151 Cal. 200, 203, 90 P. 549, 550 (1907).

64. People v. District Court of Appeal, 193 Cal. 19, 20, 222 P. 353, 354 (1924).

65. See, e.g., People v. Ford, 30 Cal. 3d 209, 635 P.2d 1176, 178 Cal. Rptr. 196 (1981), cert. denied, 455 U.S. 1003 (1982); People v. Rogers, 21 Cal. 3d 542, 579 P.2d 1048, 140 Cal. Rptr. 732 (1978); Bloom v. Municipal Court, 16 Cal. 3d 71, 545 P.2d 229, 127 Cal. Rptr. 317 (1976); Menchaca v. Helms Bakeries, 68 Cal. 2d 535, 541 n.1, 439 P.2d 903, 907 n.1, 67 Cal. Rptr. 775, 779 n.1 (1968); Chavez v. Sargent, 52 Cal. 2d 162, 188 n.10, 339 P.2d 801, 817 n.10 (1959); Ponce v. Marr, 47 Cal. 2d 159, 161, 301 P.2d 837, 839 (1956); Knouse v. Nimocks, 8 Cal. 2d 482, 66 P.2d 438 (1937); In re Estate of Kent, 6 Cal. 2d 154, 57 P.2d 901 (1936); In re Estate of Stierlen, 199 Cal. 140, 144, 248 P. 509, 510-11 (1926); Martin v. Howe, 190 Cal. 187, 211 P. 453 (1922); In re Wells, 174 Cal. 467, 163 P. 657 (1917).

66. See, e.g., Kaysser v. McNaughton, 6 Cal. 2d 248, 255-56, 57 P.2d 927, 930-31 (1937) (citing with approval two district court of appeal opimions where the supreme court had ordered that a hearing be granted). This case was criticized in Knouse v. Nimocks, 8 Cal. 2d 482, 484, 66 P.2d 438, 439. See also People v. Backus, 23 Cal. 3d 360, 392, 590 P.2d 837, 856, 152 Cal. Rptr. 710,729 (1979) (quoting vacated opimion); Chavez v. Sargent, 52 Cal. 2d 162, 187-88, 339 P.2d 801,817 (1959) (citing vacated opmion while elsewhere in opimion stating that district court of appeal judgments are vacated).

67. 8 Cal. 2d 482, 66 P.2d 438 (1937). 
if they had not been written. ${ }^{68}$

Given the broad scope of the supreme court's transfer powers, the consequences of the Noel decision are indeed far-reaching. Unfortunately, those consequences tend to defeat the division of responsibility established by the supreme court in Davis. ${ }^{69}$

\section{For Purposes of Transfer, "Cause" Equals "Case"}

The scope of the supreme court's transfer powers, and thus the impact of the vacating rule, is extensive. The constitution empowers the court to "transfer to itself a cause in a court of appeal."70 The term "cause" has been mterpreted to include "every matter decided by a district court of appeal, and operating as a final decision or disposition thereof in that court."71 Thus, the supreme court may transfer, and under the Noel rule vacate, an original proceeding in mandamus, prohibition, or certiorari pending before the district court of appeal. ${ }^{72}$

The constitution does not address the question whether a "cause" may include only part of a case. If the constitution permitted transfer of only some of the issues involved, it would authorize selective review. However, in In re Los Angeles County Pioneer Society, ${ }^{73}$ the district

68. Id. at 483-84, 66 P.2d at $438-39$ (citations omitted).

69. 147 Cal. 346, 349, 81 P. 718, 720 (1905); see supro text accompanying notes 52-56.

70. Cal. Const. art. VI, \& 12. Similiar language is also found in CAL. Const. art. V1, \& 4 (1904), and CAL. Const. art. V1, \& 2 (1879).

71. In re Wells, 174 Cal. 467, 473, 163 P. 657, 659 (1917) (emphasis added).

72. See, e.g., Moran v. District Court of Appeal, 15 Cal. 2d 527, 530, 102 P.2d 1079, 1080 (1940) (proceeding in inandamus is a "cause" under CAL. CoNST. art. VI, § 4); McDonough v. Goodcell, 13 Cal. 2d 741, 745, 91 P.2d 1035, 1038 (1939) (where mandainus proceeding transferred to supreme court, decision of district court of appeal is set aside); Rockridge Place Co. v. City Council, 178 Cal. 58, 60,172 P. 1110,1111 (1918) (supreme court has jurisdiction to vacate district court of appeal decision in an original proceeding in mandamus, prohibition, or certiorari and transfer same to itself); In re Wells, $174 \mathrm{Cal}$. at 473, $163 \mathrm{P}$. at 659 (supreme court's power to transfer includes an order admitting a person to practice law).

Formerly, the one exception to this all-inclusive definition of "cause" was a habeas corpus proceeding. See Ex parte Zany, $164 \mathrm{Cal}$. 724, 130 P. 710 (1913). Practical considerations apparently underlay the rule that a habeas corpus judgment by the district court of appeal was not a "cause," and, therefore, was not reviewable by the supreme court. If the decision were reviewable and the district court of appeal granted the writ, an intolerable sixty-day interval would result from the constitutional provision providing that the district court of appeal decision not become final until thirty days froin its pronouncement and allowing the supreme court to transfer the cause to itself another thirty days thereafter. CAL. CONST. art. V1, $\$ 4$ (I904). During this sixtyday period, the court had no authority to order the retention of custody of the prisoner, nor did the court have the authority to order a review of the habeas corpus petition once the prisoner had been discharged. See In re Wells, 174 Cal. at 473-74, 163 P. at 659-60. A similiar practical problem arose where the district court of appeal denied the writ, because where a prisoner was remanded to custody he could iminediately, without waiting the sixty days, apply to the supreme court for a new writ and have his petition tried de novo. See id. at 474, 163 P. at 660. Since 1959, authority for review after release has been provided by CAL. PENAL CODE $\$ \S 1506$ and 1507 (West 1982 ), and so a habeas corpus proceeding is presently considered a "cause."

73. 141 Cal. App. 2d 563, 297 P.2d 72 (1956). 
court of appeal rejected such an interpretation.

In that case a charitable corporation and one of its members appealed a judginent of the trial court concerning the dissolution of Pioneer and the duties of its new trustee. The court of appeal affirmed the judgment of the trial court, and ordered costs to both the member and the trustee. The supreme court, after granting Pioneer's petition for hearing, affirmed the judgunent, but without mention of costs. ${ }^{74}$

On a motion to the appellate court for reimburseinent of costs, the member contended that the order of costs remamed vahd. However, the court of appeal held that the entire case had been transferred, and therefore the entire judgment of the court of appeal had been vacated. ${ }^{75}$

Thus, as the case law presently dictates, the constitutional provision providimg the supreme court jurisdiction over "causes" transferred from the court of appeal to itself requires the nullification of the prior opimion and decision of the court of appeal. Such an interpretation restricts the ability of the supreme court to confine itself to institutional review because it must review all of the issues raised on appeal. Although some of the issues might raise important legal questions and therefore justify the transfer, others will undoubtedly be mundane. By vacating the lower court opinion and reviewing the entire case, the supreme court has severely restricted its discretion in matters before it. As a result, the court must perform both correctional and institutional review over all cases transferred to it. The rules of Noel and In re Los Angeles County Pioneer Society, therefore, prevent selective review by the court, and conflict with the intent of the 1904 amendment-as interpreted by the supreme court in People v. Davis - to limit the court's role to institutional review. ${ }^{76}$

III

\section{Circumventing the Prohibition on Selective Review}

The overcrowding at the Cahforma Supreme Court has resulted in

74. In re Los Angeles County Pioneer Soc'y, 40 Cal. 2d 852, 867, 257 P.2d 1, 10 (1953).

75. In re Los Angeles County Pioneer Soc'y, 141 Cal. App. 2d 563, 568, 297 P. 2d 72, 75-76 (1936); see also Menchaca v. Helms Bakeries, Inc., 68 Cal. 2d 535, 541 n.1, 439 P.2d 903, 907 n.1, 67 Cal. Rptr. 775, 779 n.1 (1968) (entire cause is transferred and decided on all issues); 6 B. Witkin, California Procedure $\S 617$ (2d ed. 1971 \& Supp. 1983). Cf. id. $\$ \S 130-132$ (appeals from severable judgments of the trial court, where partial appeal is allowed), and cases cited therein. One exception to the rule that a transfer of a "cause" must include all issues of the case is when the supreme court grants a hearing on the denial of a inotion to recall the remittitur made to the court of appeal. In this case, only the decision denying the motion is vacated upon transfer to the supreme court, and the supreme court will retransfer the motion to the court of appeal to reinstate its original decision if it ultimately agrees with the court of appeal. See Southwestern lnv. Corp. v. City of Los Angeles, 38 Cal. 2d 623, 630, 241 P.2d 985, 989 (1952); Heroux v. Atchison, T. \& S.F. Ry., 14 Cal. 2d 285, 287, 93 P.2d 805, 807 (1939); 6 B. WITKIN, supra, § 618.

76. See supra text accompanying notes $52-56$. 
a myriad of procedures through which the court attempts to circumvent these rules prohibiting selective review. Many of these procedures permit the court to confine itself to the goals of institutional review: overseeing the development of the law and resolving conflicts among the courts of appeal. However, none of these procedures presents a satisfactory substitute for selective review.

\section{A. Retransfer to the Court of Appeal with Instructions}

Under one method of avoiding the prohibition on selective review, the supreme court often retransfers the case back to the court of appeal with instructions. ${ }^{77}$ Such instructions may require the court of appeal to reconsider the decision in the hight of a recently decided case, ${ }^{78}$ to change the judgment in a particular manner, ${ }^{79}$ or simply to readopt the same opinion. ${ }^{80}$

The retransfer itself may occur either immediately following the grant of hearing, ${ }^{81}$ or some months later. ${ }^{82}$ The instructions accompanying the retransfer are generally considered binding upon the court of appeal. ${ }^{83}$ Thus, retransfer enables the supreme court to perform its supervisory role over the courts of appeal without having to address all of the issues involved im a case.

77. The court also retransfers cases without instructions. Although this procedure vacates the previous district court of appeal decision, it permits the supreme court only minimal supervisory power. See Comment, supra note 24, at 801-11.

78. See, e.g., People v. Seaton, Crim. 22981, Cal. Sup. Ct. Minutes, May 19, 1983, Cal. Official Rep. No. 16 (1983) (official advance sheets only) ("The above-entitled cause is retransferred to the Court of Appeal, Third District for reconsideration in light of People v. Crowson (1983) 33 Cal. 3d 623."). This procedure is known as a "transfer after hold." See 1983 JUD. CounClL CAL. ANN. REP. 80 n.b.

79. See, e.g., People v. Sesser, 269 Cal. App. 2d 707, 712-13, 75 Cal. Rptr. 297, 300-01 (1969), where the court instructed the court of appeal to strike the finding that the defendant was armed; the court of appeal modified the judgment accordingly, but left in its opinion a description of the facts stating that the defendant was armed.

80. See, e.g., Doud Lumber Co. v. Guaranty Sav. \& Loan Ass'n, 254 Cal. App. 2d 585, 60 Cal. Rptr. 94 (1967).

81. See, e.g., People v. Shaw, 2 Crim. 41739 Div. 2, Cal. Sup. Ct. Minutes, Jan. 19, 1984, Cal. Official Rep. No. 6 (1984) (official advance sheets only) ("Raymond David Schafer's petition for hearing granted and cause transferred to this court and retransferred to the Court of Appeal, Second Appellate District, Division Gne, for reconsideration in light of Carlos v. Superior Court (1983) 35 Cal. 3d 131.”).

82. See, e.g., McGhee v. Superior Court, S.F. 24566, Cal. Sup. Ct. Minutes, May 24, 1983, Cal. Official Rep. No. 16 (1983) (official advance sheets only) ("The above entitled matter, now pending in the Supreme Court, is transferred to the Court of Appeal, Third Appellate District.").

83. See, e.g., Nichols v. Canoga Indus., 83 Cal. App. 3d 956, 958, 148 Cal. Rptr. 459, 461 (1978); Atlantic Richfield Co. v. Superior Court, 51 Cal. App. 3d 168, 170, 124 Cal. Rptr. 63, 63-64 (1975). But cf. People v. Sesser, 269 Cal. App. 2d 707, 712-13, 75 Cal. Rptr. 297, 300-01 (1969) (coinplying with instructions in judgment but not in opmion). See also Grodin, supra note 16, at 527 (stating that the courts of appeal are independant bodies not bound by the supreme court instructions on retransfer); infra note 133 . 


\section{B. Retransfer to the Court of Appeal After Partial Decision}

As a second means of circumventing its prohibition on selective review, the supreme court often retransfers a cause after rendering a partial decision. For example, the court may decide one issue of a case, and then retransfer the case to the court of appeal for resolution of the remaining issues. In this manner, the supreme court decides only those issues deserving its attention.

Although the language of the constitution provides for transfers only "before decision" by the supreme court, ${ }^{84}$ the court has interpreted this phrase to inean before the decision becomes final, ${ }^{85}$ typically thirty days after filing. ${ }^{86}$ This interpretation allows the court to transfer after partial decision. Despite the attractiveness of this procedure as a ineans of permitting the court to selectively review issues, the court has made only very limited use of it. ${ }^{87}$

84. CAL. Const. art. VI, $\S 12$ ("The Supreme Court . . . may, before decision, transfer a cause from itself to a court of appeal . . . .") (emphasis added).

85. But see Comment, supra note 24 , at $791 \mathrm{n} .18$, which suggests that the court has interpreted the words "before decision" of article VI, $\$ 12$ to mean before a decision on the merits of the appeal, thereby permitting retransfer after a decision by the supreme court on a procedural issue. One problem with this rationale is, however, that retransfers after decision are not used exclusively to decide procedural issues. See, e.g., Arnel Dev. Co. v. City of Costa Mesa, 28 Cal. 3d 511, 514, 620 P.2d 565, 567, 169 Cal. Rptr. 904, 906 (1980) (upholding zoning ordinance and retransferring to court of appeal for resolution of issues not fully argued before supreme court or earlier resolved by court of appeal).

86. The California Rules of Court provide that:

A decision of the Supreme Court becomes final 30 days after filing unless the court orders a shorter time or, prior to the expiration of the 30 day period or any extension thereof, orders one or more additional periods of time not to exceed a total of 60 additional days.

CAL. CT. R. 24(a). This restriction, formally a part of the constitution, was made a court rule during the 1966 revision of article VI.

87. See, e.g., People v. Romero, 31 Cal. 3d 685, 696, 646 P.2d 824, 831-32, 183 Cal. Rptr. $663,669-70$ (1982) (deciding the issue of impeachment of the jury verdict, and retransferring for determination of remaining issues not reached by the court of appeal); Andrews v. Agricultural Labor Relations Bd., 28 Cal. 3d 781, 796, 623 P.2d 151, 159, 171 Cal. Rptr. 590, 598 (1981) (holding that administrative law officer did not err in refusing to disqualify himself, and retransferring for review of substance of the ALRB opinion not previously addressed by court of appeal); Arnel Development Co., 28 Cal. 3d at 514, 620 P.2d at 567, 169 Cal. Rptr. at 906 (upholding zoning ordinance, and retransferring for resolution of minor issues); Gonzales v. Nork, $20 \mathrm{Cal}$. 3d 500, 511, 573 P.2d 458, 465, 143 Cal. Rptr. 240, 247 (1978) (holding denial of rehef from a jury waiver not an abuse of discretion, and retransferring for resolution of other issues); Vella v. Hudgins, 20 Cal. 3d 251, 254, 572 P.2d 28, 30, 142 Cal. Rptr. 414, 416 (1977) (holding that suit to set aside trustee's sale for fraudulent inducement to default not precluded by prior adjudication of the fraud issue, and retransferring for disposition on the merits); Taylor v. Union Pac. R.R., 16 Cal. 3d 893, 895, 549 P.2d 855, 857, 130 Cal. Rptr. 23, 25 (1976) (upholding validity of waiver of jury right valid, and retransferring for deterinination of other issues); Ferguson v. Keays, 4 Cal. 3d 649, 659, 484 P.2d 70, 76, 94 Cal. Rptr. 398, 404 (1971) (in consolidated action, upholding power of court of appeal to grant relief from payınent of filing fee, setting out guidelines for doing so, and retransferring causes back to court of appeal); see also 6 B. WITKIN, supra note 75, $\S \S 619,619 \mathrm{~B}$. 


\section{Decertification of the Opinion of the Court of Appeal}

Decertification is a third, but somewhat more limited, procedure that the supreme court uses to exercise its supervisory role over the courts of appeal. Decertification permits the court to order that an opmion-already certified for publication by the court of appeal-not be published ${ }^{88}$ In this way, the court deprives the opinion of any precedential value without changing the outcome of the case.

Decertification, a practice unique to California, ${ }^{89}$ has been harshly criticized, especially because it allows the supreme court to shape the law without publicly addressing controversial issues. ${ }^{90}$ Nevertheless, the supreine court einploys this procedure approximately one hundred times a year, ${ }^{91}$ almost always to dispose of a petition for hearing. ${ }^{92}$

\section{Comments Upon the Denial of Hearing}

The supreine court has also issued cominents upon the denial of hearing that expressly approve, disapprove, or withhold approval of particular parts of a court of appeal opinion. ${ }^{93}$ These cominents do not alter the actual outcoine of the decision with respect to the litigants.

Cominents upon denial of hearing do not create binding precedent. Rather, they are simply informational in nature, and are to be used by the courts and practitioners only to determine what precedential weight should be given to the particular case. ${ }^{94}$ As such, these comments do not allow the suprenie court to nake positive decisions regarding particular issues; they permit only approval or disapproval. Thus, comments upon the denial of hearmg have only a limited and possibly confusing effect on the developinent of precedent. ${ }^{95}$

While this procedure was once extensively used, ${ }^{96}$ the practice

88. CAL. CT. R. 976(c).

89. See Gerstein, "Law by elimination": depublication in the California Supreme Court, 67 JUDiCATURE 293, 298 (1984).

90. Id. passim; Grodin, supra note 16 , at $520-23$.

91. Gerstein, supra note 89, at 294; see, e.g., Herrera v. County of Los Angeles, 2 Civ. 66231 Div. 5, Cal. Sup. Ct. Minutes, Jan. 19, 1984, Cal. Official Rep. No. 6 (1984) (Official Advance Sheets only) (decertifying case appearing at 149 Cal. App. 3d 242 in Official Advance Sheets). Decertification is occasionally used in conjunction with the retransfer procedure. See, e.g., Robinson v. Superior Court, S.F. 24185, Cal. Sup. Ct. Minutes, Jan. 5, 1984, Cal. Official Rep. No. 4 (1984) (Official Advance Sheets only) (retransferring cause to court of appeal with dircctions to refile its former opinion, while direeting the Reporter of Deeisions not to publish the opinion).

92. Gerstein, supra note 89, at 296.

93. See 6 B. WITKIN, supra note $75, \S 622$ and cases cited therein; Coinment, supra note 24 , at $811-19$.

94. See Comment, supra note 24 , at 815 .

95. See Grodin, supra note 16, at 522-23; Comment, supra note 24, at 815-17; Comment, supra note 37 , at $87-88$.

96. Between 1905, when the district courts of appeal were established, and 1938, the court issued 255 denials of hearing with qualifications. Coinment, supra note 37 , at 82. 
ceased after Justice Hauser challenged its constitutionality in $1938 .{ }^{97}$ Cominentators have since defended and encouraged comments on denial of hearing, ${ }^{98}$ but the supreine court has not yet chosen to revive the practice.

\section{E. Republication of the Opinion of the Court of Appeal}

Another procedure used by the supreme court to employ a ineans of selective review is the republication, in whole or in part, of the lower court's opmion. Republication was originally used by the court sitting in bank to adopt the opinion of one of its departinents. ${ }^{99}$ After the establishment of the district courts of appeal, the supreine court began using the same practice when deciding cases upon transfer after judgment in the district courts of appeal. The court generally republishes an appellate opimion in three distinct circumstances.

First, the court may transfer a case to itself if there appears to be some question as to the validity of the court of appeal decision. Sucli questions include whether the court below had jurisdiction, ${ }^{100}$ or whether participation by a disqualified nember invalidated the judgment. ${ }^{101}$ Since the transfer vacates the prior decision, the error involved is cured, and the supreme court can simply republish the complete opinion of the court of appeal as its own.

A dissenting member of the supreme court may also invoke republication. ${ }^{102}$ If he or she agrees with the lower court's resolution of the case, the justice may simply republish the lower court's opinion, thus saving the time-consuming process of drafting a dissent.

Finally, the supreme court may use republication to selectively review certain issues in a case. The court will review the issues it deems appropriate and write an opinion on that facet of the case. It then republishes as its own that portion of the lower court's opinion that resolves the remaining issues. ${ }^{103}$ Even though there is no question of the

97. Wires v. Little, 27 Cal. App. 2d 240, 245, 82 P.2d 388, 389 (1938).

98. See, e.g., 6 B. Wirkin, supra note 75, § 622; Comment, supra note 24, at 811-19; Comment, Comments by the Supreme Court on Denial of a Petition for Hearing, 13 S. CAL. L. Rev. 461 (1940).

99. See, e.g., Kimball v. McKee, 149 Cal. 435, 456, 86 P. 1089 (1906) (adopting part of the department's opinion).

100. See, e.g., Burns v. Peters, 5 Cal. 2d 619, 55 P.2d 1182 (1936).

101. See, e.g., Knouse v. Nimocks, 8 Cal. 2d 482, 66 P.2d 438 (1937).

102. See, e.g., Crockett v. Superior Court, 14 Cal. 3d 433, 442-47, 535 P.2d 321, 328-31, 121 Cal. Rptr. 457, 464-67 (1975) (Mosk, J., dissenting); Lindros v. Governing Bd. of the Torrance Unified School Dist., 9 Cal. 3d 524, 545, 510 P.2d 361, 375, 108 Cal. Rptr. 185, 199 (Burke, J., dissenting), cert. denied, 414 U.S. 1112 (1973).

103. Usually the supreme court will extensively edit the lower court opinion, using brackets to indicate additions or deletions. See, e.g., Agarwal v. Johnson, 25 Cal. 3d 932, 603 P.2d 58, 160 Cal. Rptr. 141 (1979); Doers v. Golden Gate Bridge Highway \& Transp. Dist., 23 Cal. 3d 180, 588 P.2d 1261, 151 Cal. Rptr. 837 (1979); People v. Reyes, 12 Cal. 3d 486, 502-03, 526 P.2d 225, 234, 
court's constitutional power to republish opinions, ${ }^{104}$ the court uses this procedure infrequently. ${ }^{105}$

\section{F. Adoption by Reference}

The supreme court recently developed yet another means of avoiding the rule against selective review. Rather than republish part of the lower court's opinion, the supreme court will sometimes adopt part of that opinion by reference. ${ }^{106}$ In addition, the court has, on at least one occasion, used adoption by reference in conjunction with republication. ${ }^{107}$

The supreme court apparently has used adoption by reference only since $1976,{ }^{108}$ and then only on a handful of occasions. ${ }^{109}$ Its himited

116 Cal. Rptr. 217, 226 (1974) (reversing conviction of one defendant, and upholding conviction of second defendant by republishing court of appeal opinion); People v. Lyons, 47 Cal. 2d 311, 314 n.1, 303 P.2d 329, 330 n.1 (1956).

104. Nothing in the California Constitution appears to prohibit republication, and the case law las expressly approved the practice. See supra text accoinpanying note 68 .

105. A searcl of California Supreine Court cases reveals that of the 123 written opinions issued between July 1, 1981 and June 30, 1982, republication was used only six timcs. It was used only three of those six times to decide less than the entire case. See Kilgore v. Younger, 30 Cal. 3d 770, 775-76, 640 P.2d 793, 796, 180 Cal. Rptr. 657, 660 (1982); People v. Superior Court, 30 Cal. 3d 193, 197, 636 P.2d 23, 25, 178 Cal. Rptr. 334, 336 (1981); People v. Meredith, 29 Cal. 3d 682, 69596, 631 P.2d 46, 54-55, 175 Cal. Rptr. 612, 620-21 (1981); see also People v. Teresimski, 30 Cal. 3d 822, 827-32, 640 P.2d 753, 755-58, 180 Cal. Rptr. 617, 619-22 (1982) (reproducing part of former opinion after hearing by United States Supreme Court).

106. For example, in People v. James, 19 Cal. 3d 99, 561 P.2d 1135, 137 Cal. Rptr. 447 (1977), the supreme court stated: "[W]ith one exception, we agree with the Court of Appeal's rcsolution of the issues there presented, and . . therefore reject the contentions as without inerit." Id. at 118, 561 P.2d at 1146, 137 Cal. Rptr. at 458. Similarly, in Sanborn v. Chronicle Publishing Co., 18 Cal. 3d 406, 556 P.2d 764, 134 Cal. Rptr. 402 (1976), the court simply "adopt[ed] that portion of the vacated Court of Appeal opinion which considered [a particular] aspect of these appcals." Id. at $410,556 \mathrm{P} .2 \mathrm{~d}$ at $765,134 \mathrm{Cal}$. Rptr. at 403.

107. People v. Meredith, 29 Cal. 3d 682, 695-96, 631 P.2d 46, 54, 175 Cal. Rptr. 612, 620 (1981).

108. See Sanborn v. Chronicle Publishing Co., 18 Cal. 3d 406, 556 P.2d 764, 134 Cal. Rptr. 402. The procedure was used, lowever, in the early part of the century to adopt the supreme court's prior opinion upon a reliearing. See, e.g., Miller \& Lux Inc. v. James, 180 Cal. 38, 48, 179 P. 174, 179 (1919) ("In the opinion of the court upon relearing, the first opinion, so far as it was adhered to by the court, was incorporated therein.").

109. A LEXIS search conducted on Jan. 27, 1984 revealed only ten occasions since its initiation in 1976 that adoption by reference has been used. See People v. Wright, $30 \mathrm{Cal}$. 3d 705, 714, 639 P.2d 267, 272, 180 Cal. Rptr. 196, 201 (1982); People v. Ford, 30 Cal. 3d 209, 215, 635 P.2d 1176, 1179, 178 Cal. Rptr. 196, 199 (1981), cert. denied, 455 U.S. 1003 (1982); People v. Bustamante, 30 Cal. 3d 88, 104, 634 P.2d 927, 937, 177 Cal. Rptr. 576, 586 (1981); People v. Collie, 30 Cal. 3d 43, 64, 634 P.2d 534, 546, 177 Ca1. Rptr. 458, 470 (1981); Highland Ranch v. Agricultural Labor Relations Bd., 29 Cal. 3d 848, 867, 633 P.2d 949, 960, 176 Cal Rptr. 753, 764 (198I); People v. Meredith, 29 Cal. 3d 682, 695, 631 P.2d 46, 54, 175 Cal. Rptr. 612, 620 (1981); People v. Hidalgo, 22 Cal. 3d 826, 828, 587 P.2d 230, 231, 150 Cal. Rptr. 788, 789 (1978); Pcople v. Scott, 21 Cal. 3d 284, 297, 578 P.2d 123, 130, 145 Cal. Rptr. 876, 883 (1978); People v. Jaunes, 19 Cal. 3d 99, 118, 561 P.2d 1135, 1146, 137 Cal. Rptr. 447, 458 (1977); Sanborn v. Chronicle Publishing Co., 18 Cal. 3d 406, 410, 556 P.2d 764, 765, 134 Cal. Rptr. 402, 403 (1976). 
use probably stems from doubt as to the constitutionality of the procedure. Such doubt recently surfaced in People v. Ford, ${ }^{110}$ wliere the majority of the supreme court adopted by reference a portion of the opinion of the court of appeal. ${ }^{111}$

Chief Justice Bird dissented in Ford on the use of adoption by reference. ${ }^{112}$ She wrote that adoption by reference violated the constitutional requirement that decisions of the supreme court and courts of appeal that determine causes sliall be given in writing witl reasons stated. ${ }^{113}$ Because the court of appeal decision had been vacated, the supreme court had failed to satisfy the writimg requirement:

When this court alludes to a nonexistent Court of Appeal opinion for the basis of its opinion, it is not giving to the litigants and the public a method by which they will be able to discern the decision and legal reasoning of this court. The Court of Appeal opinion was vacated when this court granted a hearing in this case. Yet, the inajority opinion alludes to that nonexistent Court of Appeal opinion for a resolution of a number of issues raised by the appeal. ${ }^{114}$

Justice Mosk, for the majority, defended the use of adoption by reference. He stated that it was neither a violation of the rule against selective review nor of the requirement that decisions be in writimg with reasons stated. ${ }^{115}$ First, adoption by reference represented simply an exercise of the court's "power of express 'approval or adoption" "-a power spccifically permitted by the rule vacating the court of appeal's opinion upon transfer to the supreme court. ${ }^{16}$ Second, the procedure did satisfy the constitutional requirement of a written disposition because a copy of the lower court's opinion was given to all of the parties and is available in the court's public records. ${ }^{117}$

110. 30 Cal. 3d 209, 635 P.2d 1176, 178 Cal. Rptr. 196 (1981).

111. In so doing, the majority stated that:

We have reviewed the defendant's remaining contentions. They present no new and important issue of law, and were correctly resolved by the Court of Appeal when the case was before that court. For the reasons stated by the Court of Appeal, we therefore hold each of these contentions to be without merit.

Id. at 215, 635 P.2d at 1179, 178 Cal. Rptr. at 199.

112. Id. at 218-19, 635 P.2d at 1181, 178 Cal. Rptr. at 201 (Bird, C.J., dissenting). Curiously, in People v. Collie, 30 Cal. 3d 43, 64, 634 P.2d 534, 546, 177 Cal. Rptr. 458, 470 (1981), decided just one month prior to Ford, the chief justice concurred with the majority, despite its use of the saine language to adopt by reference the court of appeal opinion. In People v. Wright, $30 \mathrm{Cal}$. 3d 705, 715-20, 639 P.2d 267, 273-76, 180 Cal. Rptr. 196, 202-05 (1982), decided only a few months after Ford, Chief Justice Bird dissented only on the merits, despite the majority's adoption by reference of the court of appeal opinion.

113. CAL. CONST. art. VI, $\$ 14$.

114. Ford, $30 \mathrm{Cal}$. 3d at 219, 635 P.2d at 1181, 178 Cal. Rptr. at 201 (Bird, C.J., dissenting).

115. Id. at 215-16, 635 P.2d at 1179-80, 178 Cal. Rptr. at 199-200.

116. Id. at 216, 635 P.2d at 1179, 178 Cal. Rptr. at 199 (quoting Knouse v. Ninocks, 8 Cal. $2 d$ 482, 66 P.2d 438 (1937)).

117. Id. 
By implication, therefore, a majority of the supreme court interprets the rule vacating the court of appeal's opinion to permit the supreme court to revive all or part of the lower court's opinion without republishing it in the official reports. ${ }^{118}$ Under this interpretation, the express approval by the supreme court of part of the court of appeal's opinion restores the validity of that part. This allows the supreme court to render a full, written-although half-published-opinion. Since the case law developing the rule vacating the court of appeal's opinion does indeed allow for the subsequent adoption of the opinion by the supreme court, ${ }^{119}$ there appears to be no reason why such adoption may not be made by reference. ${ }^{120}$

Moreover, two additional considerations suggest that adoption by reference satisfies the constitutional requirement that decisions be in writing with reasons stated. ${ }^{121}$ First, although it remains an open question, ${ }^{122}$ even short memorandum opinions appear to satisfy the requirement. ${ }^{123}$ Indeed, such opinions were used extensively by the supreme court until $1909,,^{124}$ and until more recently by the district courts of appeal. ${ }^{125}$

Similarly, the court is not required to address all issues that might arise on appeal: "An opinion is not a controversial tract, much less a

118. Id.

119. See supra text accompanying note 68 .

120. But see infra note 127 .

121. Cal. Const. art. VI, § 14.

122. See, e.g., People v. Rojas, 118 Cal. App. 3d 278, 173 Cal. Rptr. 64 (1981); 6 B. WitK1N, supra note 75, § 492; B. WITKIN, MaNuAL ON APPELLATE COURT OPINIONS $\$ \$ 131$ 1-133 (1977); Radin, supra note 9.

123. See generally 6 B. WITKIN, supra note $75, \S 497$. Short opinions also appear to be in keeping with the intent of the 1879 constitutional convention which established the writing requirement:

Now, when we require them to state the reasons for a decision, we do not mean they shall write a hundred pages of detail. We [do] not mean that they shall include the small cases, and impose on the country all this fine judicial literature, for the Lord knows we have got enough of that already. To give us the reason for it does not takc three lines. . . . Let them write short opinions in all cases, and I contend that it will not be difficult for them to write up all the decisions of the Court.

3 E. WilLis \& P. StOcKTon, supra note 9, at 1455-56 (remarks of Mr. Barbour, delegate from San Francisco). When construing constitutional provisions, the proceedings of the constitutional convention may be referred to and considered. See Fox-Woodsum Lumber Co. v. Bank of America, 7 Cal. 2d 14, 22, 59 P.2d 1019, 1022 (1936); Story v. Richardson, 186 Cal. 162, 165, 198 P. 1057, 1059 (1921); In re Smith, 152 Cal. 566, 569, 93 P. 191, 193 (1907); People v. Chapman, 61 Cal. 262, 266-67 (1882); Wallace v. Superior Court, 141 Cal. App. 2d 771, 777, 298 P.2d 69, 73 (1956).

124. The requirement that decisions be in writing with reasons stated began in 1879. $\mathrm{CAL}_{\mathrm{AL}}$ CoNST. art. VI, $\$ 2$ (1879). Nevertheless, from the beginning of the official reports through volume 149 (1906), as well as in volumes 152 (1907-1908), 154 (1908), and 155 (1909), there appears a section entitled "Cases not Reported." These decisions were usually, but not always, cases decided on the authority of another case appearing in the same volume, and contain only an abbreviated description of the decision.

125. See, e.g., Alpha Stores v. You Bet Mining Co., 18 Cal. App. 2d 767, 63 P.2d 1138 (1936). 
brief in reply to the counsel agamst whose views we decide. It is merely a stateinent of conclusions, and of the principal reasons which have led us to them."126

Since an opinion need not address all of the issues presented, nor even be more than a short memorandum opmion, adoption by reference does not appear to violate the writing requirement of article VI, section 14. Justice Mosk's interpretation of the court's role permitting the restoration of a vacated opinion of the court of appeal adds even more legitimacy to the procedure. ${ }^{127}$

126. Holmes v. Rogers, 13 Cal. 191, 202 (1859). In People v. Rojas, 118 Cal. App. 3d 278, 173 Cal. Rptr. 64 (1981), reh'g denied, 118 Cal. App. 3d 288, 174 Cal. Rptr. 91 (1981), a recent court of appeal decision, the court addressed some of the defendant's issues presented on appeal, but responded to the other issues raised by simply statimg that the "[d]efendant's remaming contentions do not merit discussion." Id. at 288, 173 Cal. Rptr. at 68 . In his petition for rehearing, the defendant asserted that such a disposition violated the constitutional requirement that decisions determining causes be im writing with reasons stated. Id. at 288, $174 \mathrm{Cal}$. Rptr. at 92 . In an unusual opimion denying the rehearing, the court of appeal responded strongly, stating "we interpret the phrase 'determines causes' to refer to disposing of the judgment or the order of the trial court and not to every corollary legal issue that may somehow be imvolved." Id. at $289,174 \mathrm{Cal}$. Rptr. at 92. Expressing its "concern that the quality of justice is being diminished by appellate backlog," id. at 290, 174 Cal. Rptr. at 93, the court found that the constitution did not require that it "set forth and dispose of, seriatim, each and every item which appellant's counsel chooses to characterize as an "issue' in the case." Id.

Similarly, in the recent case of Reserve Ins. Co. v. Pisciotta, 30 Cal. 3d 800, 640 P.2d 764, 180 Cal. Rptr. 628 (1982), the supreme court used language like that of the Rojas court to summarily dispose of several issues raised in the appeal: "We have carefully reviewed the other contentions advanced by the parties and found them to be without merit." Id. at 817,640 P.2d at $774,180 \mathrm{Cal}$. Rptr. at 638. The validity of this abbreviated disposition was apparently not questioned.

127. Adoption by reference may, however, violate the court's own publication rules. These publication rules differ from the requirement of written decisions smce the constitution does not require all written decisions to be published. Both the publication of the court's decisions and the writing requirement are governed by CAL. CoNST. art. VI, \& 14:

The Legislature shall provide for the prompt publication of such opinions of the Supreme Court and courts of appeal as the Supreme Court deems appropriate, and those opinions shall be available for publication by any person.

Decisions of the Supreme Court and courts of appeal that determine causes shall be in writing with reasons stated.

The California Rules of Court require that "[a]ll opmions of the Supreme Court shall be published in the Official Reports." CAL. CT. R. 976(a). When a portion of a court of appeal opinion is adopted by reference, that portion presumably becomes a part of the opinion of the supreme court required by Rule 976(a) to be published. However, a court of appeal opinion adopted by reference is nonetheless never published, due to a rule that "[n]o opinion superseded by the granting of a hearing, rehearing, or other judicial action shall be pubhished." CAL. CT. R. 976(d). Thus, while Rule 976(d) prohibits a court of appeal opinion from being published when the supreme court grants a hearing, Rule 976(a) appears to require publication of that portion of the opmion adopted by reference. 
IV

\section{The Adoption of Selective Review}

\section{A. Desirability}

The adoption of selective review would permit the California Supreme Court to confine itself to its proper role of performing institutional review. Ancillary issues that do not present new or important questions of law or that do not present conflicts among the districts would be left to the resolution of the existing court of appeal opinion. As a consequence, the Cahfornia court system would become more efficient. This efficiency, in turn, would permit the court to reduce its backlog, hear more cases, and enjoy greater time to focus its attention on cases before it.

The adoption of selective review represents the final step in the supreme court's process of eliminating the need to review issues important only to the particular hitigants of the case. This process began with the Davis decision, where the court decided that it would exercise its discretionary review powers only to perform its institutional duties. ${ }^{128}$ The subsequent adoption of the various procedures to circumvent the prohibition on selective review further enabled the supreme court to carry out its supervisory role while avoiding the need to review for correctness of result. Although the adoption of selective review would require a significant change in the way the appellate process operates, the procedure represents merely the culmination of a long-existing trend in the California court system.

The transformation of the supreme court into a body concerned only with imstitutional review is a proper and desirable ambition. In a two-tiered appellate system, the need for the fast and final resolution of a dispute requires the presumption that the lower appellate court is fully capable of correcting the mistakes made by the trial court. ${ }^{129}$ The supreme court would be needlessly duplicating the lower appellate court's work if it were to be concerned with applying well-settled law to facts in a particular case. "To undertake this latter function would subvert this system, duphcate work, and clog the courts."130 If instead the supreme court confines its function, it will be better able to focus its resources on its proper role of overseeing the development of the law and ensuring unifornity of decision. ${ }^{131}$

Moreover, the explicit adoption of selective review would enable

128. See supra text accompanying notes $48-58$.

129. See Joiner, The Function of the Appellate System, in Justice IN THE STATEs 104 (W. Swindler ed. 1971); Leavitt, supra note 9, at 3-4; Special Committee re Appellate Courts, supra note 9, at 32-33; Comment, supra note 24, at 788-90.

130. Joiner, supra note 129, at 104.

131. See id. at 102-07; NATIONAL Center for StATE Courts, supra note 8, at 32; Hufstedler 
the supreme court to perform strictly mstitutional review without many of the accompanying disadvantages of the procedures presently in use. For example, unlike the retransfer procedures, final settlement of the case under selective review would occur when the supreme court renders its decision. Currently, retransfer orders place an additional burden on the already overcrowded courts of appeal by requiring them to consider cases they have already once decided. Moreover, because the instructions accompanying a transfer are seldom more than a sentence or two long, the court of appeal is often left to guess as to why its prior decision was madequate. For instance, the supreme court will often retransfer a cause with directions to issue an alternative writ, but without stating a theory upon which relief is to be granted. Faced with such a problem, some courts of appeal have reacted by selecting what appears to be the most hikely theory, ${ }^{132}$ while others have more recently treated the supreme court directions as requiring only a second review of the petitioner's contentions. ${ }^{133}$ A further burden is placed upon the courts of appeal if the supreme court orders oral argument to be held upon retransfer. ${ }^{134}$ Whether the court of appeal must allow argument without such an order is an open question presently left to its discretion. ${ }^{135}$

The retransfer procedures would, nevertheless, not lose their usefulness with the adoption of selective review. For example, it would still be appropriate to retransfer a case to the court of appeal for reconsideration in light of a recently decided supreme court case unavailable to the lower court at the time of its origmal ruling. Nonetheless, selective review is more appropriate for a case presenting issues requiring the supreme court's attention. Such cases present issues which require a resolution creating binding precedent for all courts in the state. Thus, selective review would not serve as a substitute for retransfers, but as an important additional tool for the supreme court.

Republication, too, has disadvantages that make it an madequate

\& Hufstedler, supra note 25, at 278-79; Special Committee re Appellate Courts, supra note 9, at 30-33.

132. See, e.g., Atlantic Richfield Co. v. Superior Court, 51 Cal. App. 3d 168, 124 Cal. Rptr. 63 (1975).

133. See, e.g., Pedlow v. Superior Court, 112 Cal. App. 3d 368, 370, 169 Cal. Rptr. 326, 327 (1980) (discharging alternative writ ordered by supreme court where plaintiff failed to provide adequate record); Popelka v. Superior Court, 107 Cal. App. 3d 496, 500, 165 Cal. Rptr. 748, 751 (1980) (interpreting supreme court instructions to require only a second review of issues); Charlton v. Superior Court, 93 Cal. App. 3d 858, 86!, 156 Cal. Rptr. 107, 109 (1979) (interpreting supreme court instructions to issue an alternative writ to only require consideration of the petitioner's contentions, and the writing of an opinion evaluating these contentions); Krueger v. Superior Court, 89 Cal. App. 3d 934, 939, 152 Cal. Rptr. 870, 873 (1979) (discharging alternative writ ordered by supreme court because of petitioners' failure to carry their pleading burden).

134. See, e.g., Krueger, 89 Cal. App. 3d at 939, 152 Cal. Rptr. at 873.

135. See Comment, supra note 24 , at 804 n. 80 . 
substitute for selective review. Because the words of the court of appeal upon republication are transformed into the words of the supreme court, this borrowed language becomes binding upon all courts in the state. ${ }^{136}$ Given this effect, the supreme court may hesitate to republish a portion of a court of appeal opinion without a close examination of its language and reasoning. When the court so examines the opinion, much of the efficiency advantage of republication is lost. Ultimately, unless every word or phrase is to the court's liking, it may find it simpler to write its own opinion, rather than to edit the lower court's opimion.

In its present form, republication also fails to provide any efficiency advantages to the parties to the proceeding. For example, although the supreme court may grant a hearing because of its interest in only one issue involved, the attorneys may nevertheless prepare briefs and oral argument for the entire appeal. ${ }^{137}$ If the parties to the proceeding were instead informed at the outset of the issues which the supreme court considers most important, a more directed and useful brief and argument could be prepared, to the ultimate benefit of all concerned. ${ }^{138}$ Perhaps because of its sense of obligation to hear and decide the cause as if on original appeal, the court has chosen not to inform the parties $\mathrm{m}$ cases when it has used the republication procedure. In contrast, the use of selective review would presumably be accompanied by the issuance of informational comments by the supreme court upon accepting an appeal. In this way, both the court and the hitigants could take advantage of the efficiencies of selective review by focusing their attention on the pertinent issues of the case.

Even adoption by reference, perhaps the procedure most similar to

136. The courts of appeal generally follow precedent set by other courts of appeal. See P. STOLz, supra note 15, at 196. However, under the doctrine of stare decisis, courts of appeal are not as strongly bound to follow other court of appeal decisions, as they are bound to follow precedent set by the California Supreme Court. See Auto Equity Sales, Inc. v. Superior Court, 57 Cal. 2d 450, 455, 369 P.2d 937, 939-40, 20 Cal. Rptr. 321, 323-24 (1962). As a result, divergent lines of cases develop among the courts of appeal. See supra note 55 .

137. While additional briefing is not required when a cause is transferred to the supreme court, CAL. CT. R. 28, lawyers often do submit a second brief to cnsure that all the justices have a copy. The chance of the brief being carefully read by the justices, nevertheless, rcmains small. See P. Stolz, supra note 15, at 194.

138. The supreme court could either inform the parties directly, in the court's minute order of transfer, or through its weekly press release. Currently, a minute cniry ordering a cause transferred to the supreme court-for example, "Respondent's petition for hearing grantcd and cause transferred to this court"-contains no extraneous information. A press release, on the other hand, sometimes does provide information as to the eventual disposition of the cause. For example, when the release states that a cause contains a question related to one already before the court, it suggests to the reader that such a cause will be retransferrcd to the court of appeal for decision in light of the case pending, once that case has been decided by the supreme court. Such a disposition is known as a "transfer and hold." See Comment, supra note 24, at 802-04; supra note 78 . 
selective review, does not serve as an adequate substitute. Unlike selective review, adoption by reference does not give the supreme court an opportumity to completely avoid deciding some issues in a case. Yet the court may have good reason to avoid deciding certain issues because the facts may not present a good opportunity for settling the law, or the issues presented may be mundane and well-settled. Additionally, because the court of appeal opinion is not published, ${ }^{139}$ the unusual situation arises that a precedent, normally binding on all courts im the state, is available only im the advance sheets, sometimes im the unofficial reports, or buried im the court's records.

Thus, despite the myriad procedures used by the supreme court to decide only some of the issues presented im a case, selective review provides sigmificant efficiency advantages not otherwise available, and does not suffer from the many shortcomings of these alternative procedures.

\section{B. Implementation}

Impleinentation of selective review could occur in two ways. First, a constitutional amendment could specifically provide for the procedure. Second, selective review could be adopted without constitutional change by remterpretimg article VI, section 12 of the California Constitution. Such a reinterpretation would provide that the transfer of a cause from the court of appeal to the supreme court is in fact a transfer from the court of appeal, rather than from the trial court.

\section{Adoption of Selective Review by Constitutional Amendment}

At present, the state legislature is considering the adoption of selective review. Senate Constitutional amendment No. 29 would alter the present language of article VI, section 12, which now provides that:

The Supreme Court may, before decision becomes final, transfer to itself a cause in a court of appeal. It may, before decision, transfer a cause from itself to a court of appeal or from one court of appeal or division to another. The court to which a cause is transferred has jurisdiction. ${ }^{140}$

The proposed amendment would delete the words "becoines final" in section 12 and add the following provisions:

The Supreme Court may review the decision of a court of appeal in any cause.

The Judicial Council shall provide, by rules of court, for the time and procedure for transfer and for review, including, among other

139. See supra note 127.

140. Cal. Const. art. VI, § 12. 
things, provisions for review of all or part of a decision, and for remand as improvidently granted.

This section shall not apply to an appeal involving a judgment of death. ${ }^{141}$

Because this proposal explicitly grants the supreme court the power to review a court of appeal dccision, the amendment would, under the current interpretation of section 12 , permit the use of selective review. This additional power stems from the distinction made between "transfer" and "review." Because present doctrine interprets "transfer" to mean transfer of an appeal from the trial court, the resulting lack of a valid court of appeal opinion makes selective review unavailable. By granting the supreme court power to "review" a court of appeal decision, this amendment implicitly changes the effect of an order by the supreme court granting a petition for hearing of a case that has already been decided by the court of appeal. The supreme court would still take jurisdiction over the entire matter, but because it would be reviewing the appellate court's decision rather than the trial court's decision, it could choose to decide only some of the issues presented in the appeal. Thus, the amendment leaves in place the existing procedure for causes transferred to the supreme court before decision by the court of appeal, but once a decision has been rendered by the court of appeal, the cause is "reviewed" rather than "transferred."

\section{Adoption of Selective Review by Reinterpretation of Article VI, Section 12 of the California Constitution}

While the proposed constitutional amendment would attain a desirable result, ${ }^{142}$ selective review could also be adopted without consti-

141. Senate Const. amend. No. 29 (as amended in Senate, April 10, 1984) (introduced by Senator Watson, Mar. 4, 1983). Senate Constitutional amendment No. 29 is sponsored by the Judicial Council and is authored by Senator Watson. It is strongly supported by Chief Justice Bird, see Carrizosa, Profile, L.A. Daily J., Jan. 2, 1984, at 1, col. 3, as well as by the California Judges Association and the Appellate Courts Committee of the State Bar. See SENATE COMmITtee on Judiciary, 1983-84 Regular Session, Staff Report on Senate Const. amend. No. 29 (on file with the California Law Review) [hereinafter cited as SENATE CoMmitTee STAFF REPORT]. The amendment requires a two-thirds majority in each house for passage. CAL. CONST. art. XVIII, $\S 1$. If the amendment passes the legislature, it may appear on the ballot of the November 6, 1984 general election. If the amendment receives voter approval, under its own terms it would become effective six months thereafter.

142. Some potential harm may nevertheless result from Senate Constitutional amendment No. 29. First, precious legislative resources are required to negotiate the amendment successfully through the legislature. Additionally, due to the highly technical nature of the amendment, there exists an unusually high chance of voter confusion when the amendment appears on the ballot in the general election. Thus, a massive campaign will be required to adequately inform the voters on this issue.

Similarly, given the recent history of the California Supreme Court-especially of the circumstances surrounding its investigation by the Commission on Judicial Performance, see generally P. STOLz, supra note 15-there is the added possibility that such a proposal will become the 


\section{tutional change. ${ }^{143}$ Selective review would become available if the}

center of a political battle. Despite the benign motives behind the amendment, its technical nature may cause a confused public-misinformed as to the effect of the amendment on their right to appeal a case to the supreme court-to reject the amendment.

Further, the death penalty exception contained in Senate Constitutional amendment No. 29 increases the chance of voter rejection. The death penalty has long been a controversial political issue in California, and by singling out death penalty appeals for a special review procedure, Senate Constitutional amendment No. 29 could become another forum for the death penalty debate.

The rejection of Senate Constitutional amendment No. 29 by the voters would, as a practical reality, probably eliminate the ability of the supreme court-in apparent defiance of the voters' wishes-to adopt selective review on its own.

A further question remains as to whether the procedural devices contained in Senate Constitutional amendment No. 29 properly belong in the constitution. The constitution traditionally establishes the "organic law" from which later law, more amenable to change, stems. See 27 REPORT OF THE ASSEMBLY INTERIM COMM. ON CONSTITUTIONAL AMENDS. TO THE CAL. LEGISLATURE, No. 1, at 24 (Nov. 15, 1960), reprinted in 2 Appendix to the Assembly Journals (1961) [hereinafter ASSEMBLy RePORT No. 1]. The more law contained in the constitution, the less flexible that document becomes, and the more frequently it must be amended.

The California Constitution is unusually detailed, and as a result, it had required amendment over 300 times by 1960. Assembly REPORT No. I, supra, at 24 ("This patchwork method of trying to keep the Constitution up-to-date is expensive, tedious and highly inefficient."). During the discussions in the early 1960's of the possible revision of article VI governing the judiciary, both Chief Justice Gibson and Attorney General Mosk expressed a need to remove unnecessary detail from the article. See 27 REPORT OF THE ASSEMBLy INTERIM COMM. ON CONSTITUTIONAL Amendments to the Calif. Legislature, No. 2, Part II, at 10-11 (Jan. 7, 1963), reprinted in 2 Appendix to the Assembly Journals (1961). But see id, at 10-11 (comments of Mr. John A. Sutro, President of the Bar Association of San Francisco). Professor Donald P. Kommers, a political scientist and expert in the field of court organization and administration, expressed similar views:

In revising the judicial article of the California Constitution some very basic principles should be kept in mind. First, it is the nature of a constitution to embody a very broad political framework and basic principles of government. Never should a Constitution be so detailed in its provisions as to hamstring future generations in ineeting their public responsibilities, and one of the greatest of these responsibilities is seeing that justice is administered economically, efficiently, and without delay. The inadequacies of many state judicial systems have been attributed to the fact that details of court organizations and administration have been frozen into State Constitutions. A related principle is that the judicial article should be fiexible so as to give the legislature the widest possible latitude in providing the proper organization and administration of the judicial system in order to meet the ever-expanding and rising demands of modern justice.

Id. at 50-51; see also Assembly REPORT No. 1, supra, at 43 (comments of Sheldon Elliott, Professor of Law, New York University). These discussions, however, produced only piecemeal changes to article VI, and thus Professor Kommer's comments remain equally relevant to our present constitution.

143. See Report of the Chief Justice's Advisory CoMm. For an Effective PublicaTION RULE 27 n.51 (June 1, 1979) (on file with the California Law Review) [heremafter cited as REPORT] ("The rule that grant of hearing supersedes the court of appeal opinion . . . is excIusively a rule of interpretation, for nothing in the constitutional text states that nullification of the entire court of appeal opinion is a necessary consequence of a Supreme Court grant of hearing.")

This is true not only for the amendment's provision permitting selective review, but as well for the authority to transfer a case back to the court of appeal with instructions, or for remand as improvidently granted. With respect to the latter two practices, it should be noted that both are presently used with some frequency by the supreme court. See supra text accompanying note 77. The Appellate Courts Committee of the State Bar acknowledged this in its letter supporting Senate Constitutional amendment No. 29: "We note that the Supreme Court has exercised each of the powers spelled out in the amendment but would probably exercise them more often if the 
supreme court reinterpreted article VI, section 12 to provide that the transfer of a cause from the court of appeal to the supreme court is in fact a transfer of an appeal from the court of appeal and not from the trial court.

Section 12 contains two provisions concerning transfers of court of appeal decisions to the supreme court. First, section 12 specifically permits such transfers where the decision has not yet become final. ${ }^{144} \mathrm{Sec}$ ond, section 12 provides that once the supreme court orders a transfer, the supreme court has jurisdiction over the cause. The ability of the supreme court to utilize selective review, therefore, depends upon the compatibility of the above two provisions with the notion that the transferred cause is an appeal from the court of appeal, rather than from the trial court.

The first provision, providing specific authority to transfer a cause, does not place any unusual limitations on what "causes" may be transferred. "Cause" has traditionally been given "the definite meaning of mcluding every matter that could come before the court for decision." 145 While the "cause" transferred to the supreme court from the court of appeal after decision has, since People $v$. Davis,${ }^{146}$ been considered an appeal originatimg in the trial court, an appeal from the court of appeal equally conforms with the definition of "cause." Thus, the section 12 provision permitting the transfer of a "cause" from the court of appeal to the supreme court is compatible with the transfer of an appeal from the court of appeal. Therefore, the court of appeal deci-

powers were clearly set forth in the Constitution." Letter by the Appellate Courts Committee of the State Bar, in support of Senate Constitutional amendment No. 29 (referring to an earlier version of Senate Constitutional amendment No. 29 with similar language) (quoted in SENATE COMMITTEE STAFF RePORT, supra note 141, at 5-6). While the retransfer procedures have been used, this is not true with selective review. The letter thus apparently refers to the similar procedure of adoption by reference.

144. The Cahfornia Rules of Court provide that a decision of the court of appeal normally becomes final thirty days after filing, CAL. CT. R. 24(a), and the supreme court may order a transfer thirty days thereafter, or with good cause, may extend this period an additional sixty days. CAL. CT. R. 28(a).

145. Quezada v. Superior Court, 171 Cal. App. 2d 528, 530, 340 P.2d 1018, 1019 (1959) (holding that a civil contempt proceeding is a "cause" under former CAL. Const. art. V1, \$ 5 (repealed 1966), providing for the matter to b: heard by a judge pro tempore); see also In re Stevens, 197 Cal. 408, 413-14, 241 P. 88, 90 (1925) (application for readmission to the bar is a "cause" under former CAL. CoNST. art. Vl, $\$ 4$ (repealed 1966), providing for transfer of a cause from the district court of appeal to the supreme court); In re Wells, $174 \mathrm{Cal}$. 467, 471-73, 163 P. 657, 658-59 (1917) (a proceeding to revoke admission to the bar is a "cause" under former CAL. CoNST. art. Vl, $\$ 4$ (repealed 1966), providing for the transfer of a cause from the district court of appeal to the supreme court); Amos v. Superior Court, 182 Cal. App. 2d 343, 345-47, 6 Cal. Rptr. 252, 254-55 (1960) (a criminal prosecution is a "cause" under former CAL. CoNST. art. VI, $\$ 5$ (repealed 1966), providing for the matter to be heard by a judge pro tempore); 6 B. WiTkIN, supra note $75, \S 493$; supra text accompanying notes 70-75.

146. 147 Cal. 346,81 P. 718 (1905). 
sion need not be vacated, but may instead remain valid until it is superseded, either in whole or in part, by the supreme court decision.

The second provision of section 12 , whicli provides the suprene court with jurisdiction over a transferred cause, is likewise compatible with the transfer of an appeal from the court of appeal. If "cause" is interpreted to include such an appeal, then the supreme court is, by this provision, given jurisdiction over that appeal. With such jurisdiction, the supreme court has the inherent power to establish the procedure of selective review. ${ }^{147}$ As the supreme court's jurisdiction is discretionary, ${ }^{148}$ it may choose to resolve all, or only some, of the issues contained in the appeal. Since the court of appeal's decision is not circumvented in the appellate process, it will still resolve all issues not decided by the supreme court. Article VI, section 12 can, therefore, be interpreted to allow selective review.

This interpretation appears to be in accord with the purpose for which the district courts of appeal were established-to make the appellate process more efficient. The 1903 legislature considered and rejected the simple expansion of the supreme court into additional departments. ${ }^{149}$ Such a proposal would have increased the capabilities of the supreme court, but it would have required continuation of the practice of vacating the department decisions upon an in bank hearing. Instead, the legislature, with strong voter approval, adopted a hierarchical appellate court structure, the corollary of which-in virtually every other jurisdiction-was the adoption of selective review.

In contrast, the analogy upon which the present interpretation is based appears inconsistent with the history and intent behind the establishment of the district courts of appeal. When the court in Noel $v$. Smith ${ }^{150}$ looked to the procedure of in bank hearings of departmental decisions to determine the status of a court of appeal decision, the court failed to note the important difference bctween a rehearing within the same body and a review of the decision of another body in a hierarchical appellate system. By analogizing the transfer of a cause after decision by the district court of appeal to the in bank liearings, the Noel court nullified the efficiency advantages of a two-tiered appellate system. To restore the efficiency advantages of the 1904 amendment, the

147. In People v. Jordan, 65 Cal. 644, 4 P, 683 (1884) (providing for an appeal to the supreme court of a criminal action prosecuted by indictment), the court stated:

The power of courts to establish a system of procedure by means of which parties may seek the exercise of their jurisdiction, at least when a system has not been established by legislative authority, is inherent. $A$ fortiori must this be so in California, where the judicial [sic] is a separate departinent of the government under our written Constitution.

Id. at 647,4 P. at 686.

148. See supra text accompanying notes $48-51$.

149. See supra text accompanying note 39 .

150. 2 Cal. App. 158, 83 P. 167 (1905). 
constitution should now be reinterpreted so that the supreme court may fully confine itself to its proper role of carrying out institutional review.

One impediment stands in the way of such an interpretation of article VI, section 12: Rule 976(d) of the California Rules of Court. Rule 976(d) prohibits the publication of a court of appeal opinion that has been "superseded" by a grant of hearing in the supreine court. ${ }^{151}$ In recent years this rule has been cited as the basis for the rule that vacates the court of appeal judgment upon a grant of a hearing. ${ }^{152}$ Rule 976(d) appears to be inconsistent with selective review. Under selective review the court of appeal opinion is "superseded" not by the granting of a hearing, but by a subsequent inconsistent ruling. Thus, Rule 976 (d) should be amended or eliminated ${ }^{153}$ by the Judicial Council, ${ }^{154}$ if selective review is adopted.

Should the supreine court adopt the procedure of selective review,

151. The California Rules of Court state that "No opinion superseded by the granting of a hearing, rehearing, or other judicial action shall be published." CAL. CT. R. 976(d). See also supra note 127.

152. See, e.g., People v. Rogers, 21 Cal. 3d 542, 579 P.2d 1048, 146 Cal. Rptr. 732 (1978); Bloom v. Municipal Court, 16 Cal. 3d 71, 74 n.2, 545 P.2d 229, 230 n.2, 127 Cal. Rptr. 317, 318 n.2 (1976); People v. Shuey, 13 Cal. 3d 835, 533 P.2d 211, 120 Cal. Rptr. 83 (1975).

153. Should the supreme court adopt selective review, it might indeed be desirable to eliminate Rule 976(d) entirely. This would allow opinions otlerwise meeting the publication standards to serve as precedent for issues not affected by the supreme court opinion. At present, court of appeal opinions are published only if they meet the standards set forth in California Rules of Court 976(b):

No opinion of a Court of Appeal or an appellate department of the superior court may

be published in the Official Reports uniess the opinion: (1) establishes a new rule of law,

applies an existing rule to a set of facts significantly different from those stated in published opinions, or modifies, or criticizes with reasons given, an existing rule; (2) resolves or creates an apparent conflict in the law; (3) involves a legal issue of continuing public interest; or (4) inakes a signiflcant contribution to legal literature by reviewing either the development of a common law rule or the legislative or judicial history of a provision of a constitution, statute, or other written law.

Under California Rules of Court 976(c)(1), a majority of the court rendering the opinion must certify that the opinion satisfles the above requirements:

An opinion of a Court of Appeal or an appeilate department of the superior court shall

be published if a majority of the court rendering the opinion certifies, prior to the decision's finality in that court, that it meets one or inore of the standards of subdivision (b).

If a court of appeal decision does satisfy the standards of Rule $976(\mathrm{~b})$, then it should be made available to guide the public and the courts in the future. Similarly, if the supreme court has left some portion of the court of appeal opinion intact, then that portion should be made available to the public along with the supreme court opinion modifying it. This is especially true with the newly adopted rule allowing the court of appeal to selectively publish parts of its opinion, so as to keep the official reports to a manageable size. See CAL. CT. R. 976.1.

The Chief Justice's Advisory Committee for an Effective Publication Rule recognized the advantages of deleting Rule 976(d), see REPORT, supra note 143, at 27-28, and proposed the following rule as a substitute: "Published Court of Appeal opinions in cases in which the Supreme Court grants a hearing shall remain published in the Official Reports, and a notation of grant of hearing sliall iınmediately follow such opinions." Id. at $\mathbf{5 0 .}$

154. The Judicial Council's rulemaking authority stems froun CAL. Const. art. VI, § 6: "To inprove the administration of justice the council shall . . . adopt rules for court administration, practice and procedure, not inconsistent with statute ...." 
the Appellate Rules should also be amended by the Judicial Council to specifically provide for the procedure. This would place the legal profession on notice that the court intends to use selective review. Rule 20 governimg the transfer of causes is the logical place to mclude such notice. ${ }^{155}$ A clause such as the following should be adopted by the Judicial Council:

The supreme court may, upon transfer to itself of a cause decided by a court of appeal, review all or part of the court of appeal decision. Unless otherwise ordered by the supreme court, the issuance of a transfer order shall suspend the decision of the court of appeal. After the supreme court decision becomes final, the prior decision of the court of appeal, to the extent it is superseded by the supreme court decision, shall be of no force and effect. If the parties to a cause agree to a settlement after the supreme court has issued an order transferring the cause to itself, the entire court of appeal decision shall be vacated unless otherwise ordered. ${ }^{156}$

After the adoption of an appropriate rule by the Judicial Council, the supreme court should, in its discretion, issue statements with its order of transfer informing the parties which issues of the inatter transferred it will review. This permits the parties to focus both their briefs and oral arguments on those particular issues. The net result is a savings of time and expense by both the litigants and the court.

\section{CONCLUSION}

The California Supreme Court faces an unprecedented workload that demands relief. A simple and effective procedure that would assist the court in managing this workload is selective review. Selective review is presently not used because of a longstanding rule requirmg the court of appeal opinion to be vacated upon a transfer to the supreine court. This rule was adopted out of another context, witlout any discussion of its merits or relation to the constitution. While tlie supreme

\footnotetext{
155. Rule 20 provides as follows:

The transfer of causes from the Supreme Court to a Court of Appeal, or from a Court of Appeal to the Supreme Court, or from one Court of Appeal to another, or from one division thereof to another, may be made only on order of the Supreme Court. The clerk of the court from which the cause is transferred shall immediately transmit to the other court the original record, briefs and all origimal papers and exhibits on file in the cause. If the transfer is made because the appeal is taken to the wrong court, the order may direct the appellant to pay the clerk of the court to which the cause is transferred the fee required by law for the filing of the record in the first instauce. If it is so ordered and the appellant fails to pay such fee within 20 days after the mailing of the notice by the clerk that the record has beeu transmitted to his office and such filmg fee must be paid, the appeal may be dismissed.
}

CAL. CT. R. 20.

156. If the parties stipulate to a settlement after the cause has been transferred to the supreme court, the reasons for the transfer are never revealed. This places the correctness of the entire court of appeal opinion in doubt. Thus, it should be deemed a nullity. 
court has been partially able to circumvent the rule's effect, an adequate substitute has not been found. Selective review should now be adopted, whether by constitutional amendment or by a reinterpretation of the supreme court's transfer powers.

Randall Don Sosnick*

* B.S. 1981, University of California, Berkeley; third-year student, Boalt Hall School of Law, University of California, Berkeley. 